\section{Medicine and the art of trade-offs}

\author{
John Launer
}

Although you would not have realised at the time, you probably understood the idea of a trade-off before the age of 5. Perhaps you longed for a toy or other precious item belonging to a friend, but knew it was wrong to steal it, or feared being caught if you did. So you calculated what you could offer that might tempt the other personsomething you were willing to part with, but still held value in your own eyes. Intuitively, you realised that when you desire two or more things you may have to seek a compromise. Around the same age you would also have discovered that the principle applies to experiences as well as objects: for instance, you cannot watch television and play table tennis at the same time. You have to choose which of these you prefer at any given moment.

Trade-offs are not only a feature of human decision-making. They are a universal principle in the physical sciences too. In biology, the concept of trade-offs is so important that it would be reasonable to say it now stands as one of the pillars of evolutionary theory, alongside Darwin's concepts of variation and natural selection. ${ }^{1}$ The classic example of an evolutionary trade-off is that having multiple offspring will generally reduce an animal's life expectancy. This is because the energy invested in reproduction and rearing young will limit the resources available for self-preservation. ${ }^{2}$ Some trade-offs can even be demonstrated experimentally. For example, if you remove the horns of male dung beetles they will grow larger testes. ${ }^{3}$ What at first appears to be random consequence makes perfect sense in biological terms: the energy that the beetles can no longer apply to growing weaponry, and hence to fighting off rivals, has been reallocated to greater sperm manufacture. This increases the chance that any successful mating with females that still occurs will be productive.

RECOGNISING TRADE-OFFS IN MEDICINE Once you realise how trade-offs apply to all living creatures, and how central they are to biological thinking, a great deal of medicine starts to make better sense as well. For instance, if we had thicker wrist bones they would break less easily, but would inhibit wrist rotation. As evolutionary scholars Randolph Nesse and Richard Dawkins

Correspondence to Dr John Launer, Associate Editor, Postgraduate Medical Journal, London WC1H 9JP, UK; johnlauner@aol.com have pointed out, individuals could be built with thickened bones that never broke and their descendants might have fewer fractures, but they would spend extra energy moving around. Normal individuals could carry on applying their energy and calcium stores elsewhere in the body, including milk production. They would do relatively better in terms of reproduction. ${ }^{4}$

Similarly, many features of human anatomy and physiology that may seem suboptimal can be understood as representing the 'least worst' compromises that emerged over evolutionary time. These include traits that were adaptive in the ecological settings where they first emerged-like obesity and allergy - that later turned out to be maladaptive as the environment changed. Other traits such as anaphylaxis and sepsis were never beneficial in the first place but were the price humans had to pay for preserving wider physiological processes that did more good than harm overall..$^{5}$ The same principles can be applied to enhance an understanding of many conditions in psychiatry, including schizophrenia and depression. ${ }^{6}$ As Nesse and Dawkins argue, 'doctors who understand the body in evolutionary terms will make better decisions for their patients because they will have a better sense of what it is that they are actually doing'.

I would go further. By operating on the universal principle of trade-offs, biology actually offers us a model for practising medicine as well. As every doctor knows, there is almost no action that does not entail both potential gains and the concomitant risk of losses - in other words, the need for tradeoffs. Evidence-based medicine can point us towards what works in the notional average patient while causing the least harm, and the model of shared decision-making teaches us how to discuss such information with individual patients, but I suggest we need to go a step further: to conceptualise medicine itself as the art of managing trade-offs.

\section{BALANCING DESIRABLES}

To understand this better, think of any patient you may have seen in the last few days. Presumably, you made a decision about how long to spend with them, and when to terminate the encounter in order to allocate your time to the needs of other patients or yourself-in other words, a trade-off. While consulting with them, you are likely to have computed in your mind a whole range of other decisions, including whether to recommend a change to their treatment, the advantages and disadvantages of doing so, possibly the cost involved, and how much of this you needed to explain to them and how. You may have made dozens of similar decisions within a short space of time-some consciously, and others as a result of ingrained habit. Each of these microdecisions entailed a calculation of trade-offs. In essence, you were enacting a continual evolutionary process as your brain weighed possible choices against each other. Indeed, it has been argued that the brain might itself function as a trade-off calculator, honed by evolution in order to balance options that require less mental and physical energy against those requiring more. ${ }^{7}$

Once you start to notice trade-offs, you begin to see how they are everywhere. More important, you become aware of how often people fail to acknowledge them and describe their decision-making as if it was always optimal rather than inevitably based on compromise. This happens regularly not only in medicine but in politics as well. During the COVID-19 pandemic, for example, there was a clear choice for governments about whether or not to order an immediate and strict national lockdown, while knowing this would inflict serious consequences on their economies. Some governments like New Zealand did so. Others, including those in the USA and the UK, insisted on denying there was a dilemma at all. They claimed it was possible both to protect their citizens from the virus and to preserve their economies. As a result, they followed an unclear and vacillating course that led to a greater loss of both desirables: life and economic well-being. In effect, they behaved like children who believed they could keep their own toy and acquire the other toy they wanted as well. Failure to recognise that a trade-off was unavoidable led to the worst possible consequences.

Randolph Nesse has written: 'Anyone who thinks that evolutionary medicine sees the body as perfect is not paying attention. A deep evolutionary view reveals the bodies of all organisms as bundles of trade-offs, compromises and limitations that ensure that perfection is impossible'. ${ }^{8}$ I believe the same is true of medical practice, in politics and indeed our personal decisions from childhood onwards. We need to understand and teach the importance of trade-offs and the way they govern so many aspects of our lives.

Twitter John Launer @JohnLauner.

Funding The authors have not declared a specific grant for this research from any funding agency in the public, commercial or not-for-profit sectors.

Competing interests None declared.

Patient consent for publication Not required. 


\section{On reflection}

Provenance and peer review Not commissioned; internally peer reviewed.

(C) Author(s) (or their employer(s)) 2020. No commercial re-use. See rights and permissions. Published by BMJ.

D Check for updates

To cite Launer J. Postgrad Med J 2020;96:575-576.

Postgrad Med J 2020;96:575-576.

doi:10.1136/postgradmedj-2020-138575

\section{REFERENCES}

1 Agrawal AA, Conner JK, Rassman S. Tradeoffs and negative correlations in evolutionary ecology. In: Bell MA, Eanes WF, Futuyama DJ, et al., eds. Evolution after Darwin: the first 150 years. Sunderland, MA: Sinauer Associates, 2010: 243-286.

2 Stearns S What are trade-offs? Available https://www. youtube. com $/$ watch? $v=c 7$ suzKoZWpE\&feature $=$ youtu. be (accessed 21 Jun 2020)

3 Simmons LW, Emlen DJ. Evolutionary trade-off between weapons and testes. PNAS 2006:103:16346-51.

4 Nesse RM, Dawkins R. Evolution: medicine's most basic science. In: Warrell DA, Cox TM, Firth JD, et al., eds.
Oxford textbook of medicine. 5th edn. Oxford: Oxford University Press, 2010: pp.12-15.

5 Medzhitov R. Origin and physiological roles of inflammation. Nature 2008:454:428-35.

6 Nesse R. Evolution at 150: time for truly biological psychiatry. B J Psych 2009:195:471-471.

7 Cohen JD, McClure SM, Yu AJ. Should I stay or should I go? How the human brain manages the trade-off between exploitation and exploration. Phi Trans $R$ Soc B 2007;362:933-42.

8 Nesse R. Darwinian medicine is evolutionary medicine. Available https://www.randolphnesse.com/articles/dar winian-medicine (accessed 21 Jun 2020) 